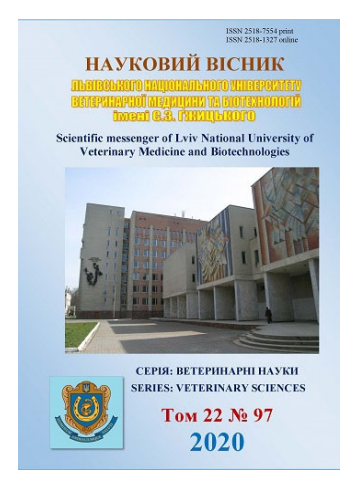

\section{Науковий вісник Дьвівського національного університету ветеринарної медицини та біотехнологій імені С.3. Гжицького. Серія: Ветеринарні науки}

Scientific Messenger of Lviv National University of Veterinary Medicine and Biotechnologies. Series: Veterinary sciences doi: $10.32718 /$ nvlvet9707 https://nvlvet.com.ua/index.php/journal

UDC 636.085.11:13

\title{
Evaluation of different methods of control of quality of grain raw materials
}

\author{
G. V. Kushnir ${ }^{1}$, I. I. Zraylo르, T. R. Levytskyy ${ }^{1}$, B. V. Gutyj ${ }^{3}$, G. Y. Fedor ${ }^{1}$, B. I. Nazar ${ }^{1}$, L. V. Kurylas ${ }^{1}$, \\ G. Y.Nedilka ${ }^{1}$, O. M. Vilha ${ }^{1}$ \\ ${ }^{1}$ State Scientific-Research Control Institute of Veterenary Medicinal Products and Feed Additives, Lviv, Ukraine \\ ${ }^{2}$ Lviv bakery of bakery products, Lviv, Ukraine \\ ${ }^{3}$ Stepan Gzhytskyi National University of Veterinary Medicine and Biotechnologies, Lviv, Ukraine
}

\section{Article info}

Received 24.01.2020

Received in revised form 24.02.2020

Accepted 25.02.2020

State Scientific-Research Control Institute of Veterenary Medicinal

Products and Feed Additives,

Donetska Str., 11, Lviv,

79019, Ukraine.

Tel.:+38-098-58-52-921

E-mail:galmwi@ukr.net

Lviv bakery of bakery products,

B. Khmelnitsky Str., 88 ,

Lviv, 79019, Ukraine.

Stepan Gzhytskyi National University of Veterinary

Medicine and Biotechnologies,

Pekarska Str., 50, Lviv,

79010, Ukraine.
Kushnir, G. V., Zraylo, I. I., Levytskyy, T. R., Gutyj, B. V., Fedor, G. Y., Nazar, B. I., Kurylas, L. V., Nedilka, G. Y., \& Vilha, O. M. (2020). Evaluation of different methods of control of quality of grain raw materials. Scientific Messenger of Lviv National University of Veterinary Medicine and Biotechnologies. Series: Veterinary sciences, 22(97), 39-42. doi: 10.32718/nvlvet9707

The article highlights the need of the control of the quality of grain raw materials, because the increasing of the competitiveness of the grain industry is one of the leading in the national agrarian economy of Ukraine and largely its determines the place in the global agrarian market. In competition, only those enterprises retain and improve their position in the market, which consistently work to support and improve the quality of the products according to the important indicators for consumers. The main indicators of the grain quality are: protein content, and also humidity, smell, impurities, crude fat, ash content, etc. Todays, domestic enterprises introduce into the manufacturing the unique scientific and technical developments, which allow quickly and qualitatively conduct the research of raw materials and finished products. However, sometimes when controlling grain raw materials on such enterprises where the modern (spectrometric) research methods are used, some physico-chemical parameters do not coincide with the normative (arbitration) research methods. Therefore, in a comparative aspect were investigated samples of soybean, corn, barley and rapeseed by some qualitative indicators, such as humidity, crude protein and fat. By comparing two methods, it was found out that in the soybean and corn samples, both the arbitrage and the spectrometric methods were almost identical. In some rapeseed and barley samples, the difference between the same samples was small and was not more than $4.8 \%$. In determining the crude protein in the same samples in soybeans, the difference was from 0.9 to $5.1 \%$, corn grains - 2.6-5.6\%, barley grains 0.9 to $5.8 \%$, rapeseed - 1.4-9.8\%. In determining the fat content of identical samples in soybeans, the difference was small and ranged from 3.8-6.2\%, corn grains 2.6-4.8\%, barley grains $-4.2-6.4 \%$, seeds rapeseed - 7.1-11.6\%. In the conducted interlaboratory researchers, in determining moisture, crude protein and fat in grain and oil raw materials, by both arbitration and spectrometric methods it was found out, that the results of the studies were within the statistically probable error, which indicate on the high efficiency the last one. In addition, the values of qualitative indicators of the researches samples responses the requirements of regulatory documents.

Key words: crude protein, crude fat, humidity, cereals and oilseeds, arbitration methods, spectrometric methods.

\section{Оцінка різних методів контролю якості зернової сировини}

\author{
Г. В. Кушнір ${ }^{1}$, І. І. Зрайло ${ }^{2}$, Т. Р. Левицький ${ }^{1}$, Б. В. Гутий ${ }^{3}$, Г. Ю. Федор ${ }^{1}$, Б. І. Назар ${ }^{1}$, Л. В. Курилас $^{1}$, \\ Г. Ю. Неділька ${ }^{1}$, О. М. Вільха ${ }^{1}$ \\ ${ }^{1}$ Державний науково-дослідний контрольний інститут ветеринарних препаратів та кормових добавок, \\ м. Львів, Україна \\ ${ }^{2}$ Львівський комбінат хлібопродуктів, м. Львів, Украӥна
}


3.Львівський національний університет ветеринарної медицини та біотехнологій імені С. 3. Гюицького, м. Львів, Україна

У статті висвітлено необхідність контролю якості зернової сировини, оскільки підвищення конкурентоспроможності зернової галузі є однією із провідних у національній аграрній економіці Украйни та значною мірою визначає ї̈ місце на світовому аграрному ринку. У конкурентній боротьбі лише ті підприємства зберігають і поліпиують своє становище на ринку, які послідовно ведуть роботу з підтримання і вдосконалення якості продукиії за важливими для споживачів показниками. Основними показниками якості зерна є вміст у ньому білка, а також вологість, запах, домішки, сирий жир, зольність тощзо. Сьогодні на вітчизняних підприємствах впроваджують у виробництво унікальні науково-технічні розробки, які дозволяють швидко та якісно проводити дослідження сировини та готової продукції. Однак інколи при контролюванні зернової сировини на таких підприємствах, де використовують сучасні (спектрометричні) методи досліджень, деякі фізико-хімічні показники не збігаються з нормативними (арбітражними) методами досліджень. Тому в порівняльному аспекті досліджували зразки сої, кукурудзи, ячменю та ріпаку за деякими якісними показниками, а саме вологістю, сирим протеїном та жиром. При порівнянні двох методів було встановлено, щяо y зразках сої та кукурудзи як арбітражним, так і спектрометричним методами результати досліджень майже збігалися. В окремих зразках ріпаку та ячменю різниия між однаковими зразками була невеликою і становила не більше ніж 4,8 \%. При визначенні сирого протеїну в однакових зразках у бобах сої різниия становила від 0,9 до 5,1 \%, зерні кукурудзи - 2,6-5,6 \%, зерні ячменю - 0,9 до 5,8\%, насінні ріпаку - 1,4-9,8\%. При визначенні вмісту жиру в однакових зразках у бобах сої різниия була невелика і коливалася в межах 3,8-6,2\%, зерні кукурудзи 2,6-4,8\%, зерні ячменю - 4,2-6,4\%, насінні ріпаку - 7,1-11,6 \%. При проведенні міжлабораторних випробувань при визначенні вологості, сирого протеїну та жиру в зерновій та олійній сировині як арбітражними, так і спектрометричним методами було встановлено, щуо результати досліджень перебували в межах статистично вірогідної похибки, що вказує на високу ефективність останнього. Окрім того, значення якісних показників дослідних зразків відповідали вимогам нормативних документів. K

Ключові слова: сирий протеїн, сирий жир, вологість, зернові та олійні культури, арбітражні методи, спектрометричні ме-

\section{Вступ}

Проблема забезпечення і підвищення конкурентоспроможності зернової галузі є однією із провідних у національній аграрній економіці. Це пояснюється стратегічним значенням зерна як товару на внутрішньому ринку, а також його роллю як провідного експортного товару вітчизняних аграрних підприємств. При цьому його частка в експортному потенціалі постійно зростає. Саме тому конкурентоспроможність зернової продукції значною мірою визначає конкурентоспроможність України на світовому аграрному ринку. Зернове виробництво - це галузь, продукція якої завжди була, є і буде одним із найважливіших джерел багатства будь-якої держави. У світовому землеробстві зернові культури постійно домінували, а зерно i нині залишається найважливішим і стратегічним продуктом сільського господарства. Збільшення виробництва i заготівлі зерна різних культур сприяє поліпшенню добробуту населення та забезпечення їх продуктами харчування, забезпечує запасами насіння на посівні цілі, борошномельні, хлібопекарські, кондитерські, харчові підприємства - сировиною, тваринництво - кормами (Avramenko \& Kushnir, 2015).

Актуальність теми. Для забезпечення конкурентоспроможності вітчизняної зернової продукції на внутрішньому й зовнішньому ринках зерна пріоритетними $\epsilon$ якість і безпека продукції. Володіючи великими потенційними можливостями у виробництві зернових культур, Україна здатна забезпечити стабільне постачання зерна на міжнародні ринки (Baban, 2018).

Хоча Україна і $є$ активним учасником на світовій арені, проте в умовах відкритості ринку незадовільна конкурентоспроможність вітчизняних зерновиробників пов'язана 3 низькою якістю українського зерна, оскільки наявність на зовнішніх ринках ідентичної продукції, яка відповідає сучасним стандартам, не дає можливості українським товаровиробникам одержувати належні прибутки. Україна має гіркий досвід, коли на світовому ринку наше зерно неодноразово затримували 3 претензіями щодо його якості, яка не відповідала вимогам продовольчого зерна (Shpychak \& Bodnar, 2014).

У конкурентній боротьбі лише ті підприємства зберігають і поліпшують своє становище на ринку, які послідовно ведуть роботу з підтримання і вдосконалення якості продукції за важливими для споживачів показниками. Основним показником якості зерна $є$ вміст у ньому білка, в тому числі розчинного білка клейковини. 3 його підвищенням є можливість виробити значно більше хлібобулочних виробів, істотно підвищити їхні смакові якості, досягти більшого приросту живої маси тварин тощо. У світовій практиці, крім вмісту білка, до важливих показників якості зерна належать його вологість, запах, домішки, сирий жир, зольність, тощо (Zakharina, 2014). Від якості зерна значною мірою залежить його ціна.

Сьогодні на вітчизняних підприємствах впроваджують у виробництво унікальні науково-технічні розробки, які дозволяють швидко та якісно проводити дослідження сировини та готової продукції. Однак інколи при контролюванні зернової сировини на таких підприємствах, де використовують сучасні (спектрометричні) методи досліджень, деякі фізико-хімічні показники не збігаються 3 нормативними (арбітражними) методами досліджень.

Тому метою нашої роботи було проведення міжлабораторних випробувань при визначенні деяких показників, а саме вологості, сирого протеїну та жиру як нормативними (арбітражними), так і сучасними (спектрометричним) методами. 


\section{Матеріал і методи досліджень}

Визначення сирого протеїну проводили методом К'єльдаля згідно з ДСТУ ISO 20483:2016, жир - за знежиреним залишком в апараті Сокслета згідно 3 ГОСТом 13496.15-97, вологість визначали повітрянотепловим методом згідно з ГОСТом 13586.5-93.

Як альтернативу нормативним методам використовували спектрометричний метод. Згідно з ДСТУ 4117:2007, на приладі Infratek ${ }^{\text {tm }} 1241$ данської компаніï "Foss electric" визначали вологість, сирий протеїн та жир.

\section{Результати та їх обговорення}

В порівняльному аспекті досліджували зразки сої, кукурудзи, ячменю та ріпаку. Відомо, що одним із чинників, від якого залежить якість зерна продовольчого призначення, зберігання протягом усього терміну та підтримання високої життєздатності посівного матеріалу всіх культур, є вологість. Підвищений вміст вологи в зерні активізує фізико-хімічні та фізіологічні процеси (дихання, проростання, розщеплення високомолекулярних біополімерів, активізація ферментів, набухання). На поверхні вологого зерна починають швидко розвиватися мікроорганізми, а також у зерновій масі збільшується число комах, кліщів та інших шкідників, що призводить до великих втрат зерна $\mathrm{i}$ погіршення його якості. Зокрема, зерно пшениці озимої за низької вологості можна закладати на довготривале зберігання, а за підвищеної - зберігати лише до трьох місяців без погіршення його посівних властивостей. Оптимальною вологістю зберігання зернових $є$ межа від 7 до $14 \%$, проте для тривалого зберігання вона повинна бути на 1-2 \% нижчою. Крім того, для олійних культур, в яких $\epsilon$ високий вміст жиру, вологість повинна бути на рівні 6-8 \%, що забезпечуе не тільки оптимальне зберігання, а й зберігає якісні показники зерна (Podpriatov et al., 2014).

\section{Таблиця 1}

Визначення якісних показників олійних та зернових культур

\begin{tabular}{|c|c|c|c|c|c|c|}
\hline \multirow{2}{*}{ № зразка } & \multicolumn{3}{|c|}{ Арбітражні методи досліджень } & \multicolumn{3}{|c|}{ Спектрометричні методи досліджень } \\
\hline & Вологість, \% & Сирий протеїн, \% & Сирий жир, \% & Вологість, \% & Сирий протеїн, \% & Сирий жир, \% \\
\hline \multicolumn{7}{|c|}{ Боби сої } \\
\hline 1 & 10,5 & 34,9 & 19,1 & 10,5 & 33,9 & 18,1 \\
\hline 2 & 9,9 & 36,8 & 17,7 & 10,3 & 37,2 & 16,6 \\
\hline 3 & 10,3 & 35,3 & 19,7 & 10,3 & 34,4 & 18,5 \\
\hline 4 & 11,7 & 37,4 & 18,6 & 11,6 & 36,1 & 17,7 \\
\hline 5 & 12,6 & 38,0 & 18,1 & 12,4 & 37,0 & 17,4 \\
\hline 6 & 12,4 & 41,4 & 18,5 & 12,4 & 39,3 & 19,2 \\
\hline 7 & 7,3 & 38,7 & 20,3 & 7,3 & 36,7 & 19,4 \\
\hline 8 & 10,3 & 39,7 & 17,9 & 10,0 & 38,8 & 16,8 \\
\hline 9 & 10,2 & 37,1 & 18,1 & 10,4 & 36,8 & 18,9 \\
\hline 10 & 7,8 & 35,8 & 18,9 & 7,7 & 35,5 & 18,0 \\
\hline \multicolumn{7}{|c|}{ Зерно кукурудзи } \\
\hline 1 & 15,6 & 10,2 & 3,1 & 15,8 & 9,7 & 3,2 \\
\hline 2 & 12,3 & 10,6 & 2,8 & 12,8 & 10,0 & 2,9 \\
\hline 3 & 13,3 & 9,5 & 3,0 & 13,5 & 9,0 & 3,1 \\
\hline 4 & 11,9 & 11,2 & 2,7 & 11,4 & 10,9 & 2,8 \\
\hline 5 & 10,4 & 8,6 & 3,1 & 10,6 & 8,2 & 3,2 \\
\hline 6 & 9,9 & 7,5 & 2,5 & 10,1 & 7,1 & 2,4 \\
\hline 7 & 10,3 & 10,5 & 3,8 & 10,3 & 11,0 & 3,7 \\
\hline 8 & 10,2 & 11,0 & 3,2 & 10,3 & 11,6 & 3,3 \\
\hline 9 & 11,4 & 11,8 & 4,2 & 11,5 & 12,2 & 4,2 \\
\hline 10 & 10,2 & 9,6 & 4,1 & 10,5 & 10,0 & 4,3 \\
\hline \multicolumn{7}{|c|}{ Насіння ріпаку } \\
\hline 1 & 5,9 & 21,4 & 39,0 & 6,1 & 21,1 & 41,5 \\
\hline 2 & 5,5 & 20,7 & 38,1 & 5,7 & 22,5 & 40,1 \\
\hline 3 & 5,2 & 19,8 & 36,7 & 5,4 & 22,2 & 38,3 \\
\hline 4 & 5,3 & 21,3 & 39,0 & 5,4 & 23,9 & 41,4 \\
\hline 5 & 5,4 & 20,5 & 38,2 & 5,6 & 22,4 & 39,8 \\
\hline 6 & 5,3 & 20,9 & 39,4 & 5,2 & 22,4 & 41,4 \\
\hline \multicolumn{7}{|c|}{ Зерно ячменю } \\
\hline 1 & 12,5 & 11,9 & 1,4 & 12,2 & 11,2 & 1,3 \\
\hline 2 & 11,2 & 10,5 & 2,2 & 11,7 & 11,1 & 2,0 \\
\hline 3 & 11,8 & 11,5 & 1,6 & 12,2 & 12,0 & 1,6 \\
\hline 4 & 10,6 & 10,2 & 1,9 & 11,1 & 10,8 & 2,1 \\
\hline 5 & 9,7 & 12,4 & 2,0 & 10,0 & 13,0 & 2,2 \\
\hline 6 & 10,9 & 10,8 & 1,7 & 10,9 & 10,7 & 1,9 \\
\hline
\end{tabular}


При визначенні вологості арбітражним методом у зразках сої ці величини перебували в межах 7,3$12,6 \%$, зерні кукурудзи - 9,9-15,6 \%, насінні ріпаку $5,2-5,9 \%$, насінні ячменю - 9,7-12,5\%, а спектрометричним відповідно - 7,3-12,4\%, 10,1-15,8\%, 5,2$6,1 \%, 10,0-12,2 \%$. При порівнянні двох методів було встановлено, що у зразках сої та кукурудзи як арбітражним, так і спектрометричним методами результати досліджень майже збігалися. В окремих зразках ріпаку та ячменю різниця між однаковими зразками була невеликою і становила не більше ніж 4,8 \% (табл. 1).

У світовій практиці до важливих показників якості зерна належить білок. Замінити білки в харчуванні людини і годівлі тварин іншими речовинами неможливо, оскільки всі найважливіші життєві процеси в живому організмі (обмін речовин, здатність рости і розвиватися, розмноження тощо) пов'язані з білками.

В Україні генетичні можливості різних сортів зернових і олійних культур можуть давати урожай з високим вмістом білка, зокрема створено сорти сої, які можуть давати врожай з вмістом білка в межах 40,1 до 48,3 \% (Lavrova et al., 2018). Однак сьогодні вміст білка в бобах сої в силу різних причин не перевищує 29,9-36,0 \%, що веде до зниження прибутковості зернової галузі та й конкурентоспроможності зерновиробництва (Baban, 2018).

При визначенні сирого протеїну в бобах сої арбітражним методом встановили, що ці величини перебували в межах 34,9-41,4 \%, зерні кукурудзи - 7,5$11,8 \%$, насінні ріпаку - 19,8-21,4 \%, насінні ячменю 10,2-12,4 \%, а спектрометричним відповідно - 33,9$39,3 \%, 7,1-12,2 \%, 21,1-23,4 \%, 10,7-13,0 \%$. При порівнянні величин однакових зразків у бобах сої різниця становила від 0,9 до 5,1 \%, зерні кукурудзи 2,6-5,6 \%, зерні ячменю - 0,9 до 5,8 \%, насінні ріпаку $-1,4-9,8 \%$.

При дослідженні зернової сировини особливу увагу звертають на визначення вмісту сирого жиру. Сирий жир з рослинної сировини використовується як структурна речовина в побудові клітини та $є$ джерелом ненасичених жирних кислот - лінолевої, ліноленової та арахідонової. Ці жирні кислоти не синтезуються в організмі тварин і $є$ незамінними в їхньому живленні. За їх нестачі у раціонах сповільнюється ріст, послаблюється опірність організму тварин до несприятливих чинників навколишнього середовища, у тому числі інфекційних агентів, спостерігаються ураження шкіри, знижується продуктивність і відтворна здатність. Крім того, з жиром зернових та олійних культур до організму надходять жиророзчинні вітаміни.

При визначенні вмісту сирого жиру арбітражним методом у зразках сої ці величини перебували в межах 17,7-20,3\%, зерні кукурудзи - 2,5-4,2\%, насінні ріпаку - 36,7-39,4 \%, насінні ячменю - 1,4$2,2 \%$, а спектрометричним відповідно - 17,4-19,4\%, $2,8-4,3 \%, 38,3-41,5 \%, 1,3-2,2 \%$. При визначенні вмісту жиру в однакових зразках у бобах сої різниця була невелика і коливалася в межах - 3,8-6,2 \%, зерні кукурудзи 2,6-4,8 \%, зерні ячменю - 4,2-6,4\%, насінні ріпаку $-7,1-11,6 \%$.

\section{Висновки}

За проведення міжлабораторних випробувань при визначенні вологості, сирого протеїну та жиру в зерновій сировині як арбітражними, так і спектрометричним методами було встановлено, що результати досліджень перебували в межах статистично вірогідної похибки, що вказує на високу ефективність останнього. Значення якісних показників дослідних зразків відповідали вимогам нормативних документів.

\section{References}

Avramenko, T. P., \& Kushnir, O. S. (2015). Shliakhy pidvyshchennia konkurentospromozhnosti ta yakosti zernovyrobnytstva v Ukraini. Naukovyi visnyk Khersonskoho derzhavnoho universytetu, 11(1), 49-53. http://www.ej.kherson.ua/journal/economic_11/11.pdf (in Ukrainian).

Baban, T. O. (2018). Konkurentni perevahy ukrainskoho zerna pry formuvanni eksportnoho potentsialu. Visnyk KhNTUSH. Ekonomichni nauky. Kharkiv: KhNTUSH, 191, 131-141. http://journals.uran.ua/index.php/ wissn021/article/view/129234 (in Ukrainian).

Lavrova, H. D., \& Hanzhelo, O. I. (2018). Vysokobilkovi linii soi selektsii SHI - NTsNS. Tezy dopovidei Kh mizhnarodnoi naukovoi konferentsii "Kormy i kormovyi bilok", 4-5 lypnia 2018 r. Vinnytsia: Dilo, 100 (in Ukrainian).

Podpriatov, H. I., Bober, A. V., \& Yashchuk, N. O. (2014). Yakisna i bezpechna zernova produktsiia: umovy otrymannia, zberihannia ta napriamy vykorystannia. Monohrafiia. K.: TsP "Komprynt" (in Ukrainian).

Shpychak, O. M., \& Bodnar, O. V. (2014). Vyhody ta problemy eksportu zerna z Ukrainy Ekonomika APK, 10, 5-16. http://nbuv.gov.ua/UJRN/E_apk_2013_10_3 (in Ukrainian).

Zakharina, O. V. (2014). Upravlinnia yakistiu zerna u mekhanizmi zabezpechennia konkurentospromozhnosti silskohospodarskykh pidpryiemst. Visnyk Zhytomyrskoho natsionalnoho ahroekolohichnoho universytetu, 1-2(2), 153-162. http://nbuv.gov.ua/ UJRN/Vzhnau_2014_1-2\%282\%29_20 (in Ukrainian). 